Oxidative Stress, DNA, Cell Cycle/Cell Cycle Associated Proteins and Multidrug Resistance Proteins: Targets of Human Amniotic Membrane in Hepatocellular Carcinoma A. C. Mamede, S. Guerra, M. Laranjo, K. Santos, M. J. Carvalho, T. Carvalheiro, P. Moura, A. Paiva, A. M. Abrantes, C. J. Maia, et al.

Pathology \& Oncology Research Official Journal of the Arányi Lajos Foundation

ISSN 1219-4956

Pathol. Oncol. Res.

DOI 10.1007/s12253-016-0053-x

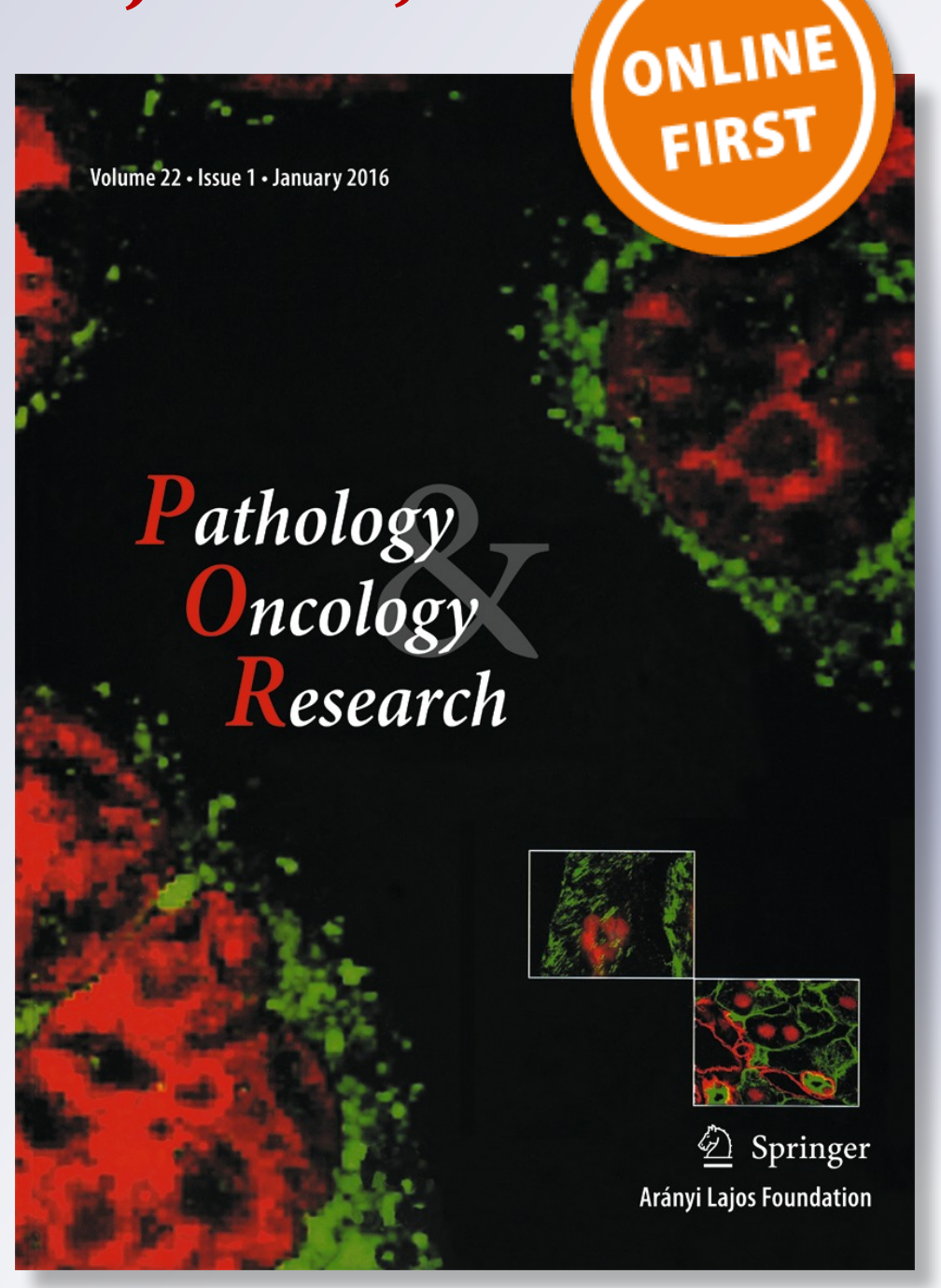

望 Springer 
Your article is protected by copyright and all rights are held exclusively by Arányi Lajos Foundation. This e-offprint is for personal use only and shall not be self-archived in electronic repositories. If you wish to self-archive your article, please use the accepted manuscript version for posting on your own website. You may further deposit the accepted manuscript version in any repository, provided it is only made publicly available 12 months after official publication or later and provided acknowledgement is given to the original source of publication and a link is inserted to the published article on Springer's website. The link must be accompanied by the following text: "The final publication is available at link.springer.com". 


\title{
Oxidative Stress, DNA, Cell Cycle/Cell Cycle Associated Proteins and Multidrug Resistance Proteins: Targets of Human Amniotic Membrane in Hepatocellular Carcinoma
}

\author{
A. C. Mamede ${ }^{1,2,3,4} \cdot$ S. Guerra ${ }^{1}$ - M. Laranjo ${ }^{1,3,4} \cdot$ K. Santos $^{1}$ - M. J. Carvalho Ca,3,5 $^{1,3}$ \\ T. Carvalheiro ${ }^{6}$ - P. Moura ${ }^{5}$ - A. Paiva ${ }^{7}$ - A. M. Abrantes ${ }^{1,3,4}$ - C. J. Maia ${ }^{2}$. \\ M. F. Botelho ${ }^{1,3,4}$
}

Received: 10 January 2016 / Accepted: 7 March 2016

(C) Arányi Lajos Foundation 2016

\begin{abstract}
The anticancer effects of human amniotic membrane (hAM) have been studied over the last decade. However, the action mechanisms responsible for these effects are not fully understood until now. Previously results reported by our team proved that hAM is able to induce cytotoxicity and cell death in hepatocellular carcinoma (HCC), a worldwide high incident and mortal cancer. Therefore, this experimental study aimed to investigate the cellular targets of hAM protein extracts (hAMPE) in HCC through in vitro studies. Our results showed that hAMPE is able to modify oxidative stress environment in all HCC cell lines, as well as its cell cycle. hAMPE differently targets deoxyribonucleic acid (DNA), P21, P53, $\beta$-catenin and multidrug resistance
\end{abstract}

A. C. Mamede and S. Guerra contributed equally to this work.

A. C. Mamede

ana_mamede@hotmail.com

1 Biophysics Unit, Faculty of Medicine, University of Coimbra, Azinhaga de Santa Comba - Celas, 3000-548 Coimbra, Portugal

2 CICS-UBI, Health Sciences Research Centre, University of Beira Interior, Covilhã, Portugal

3 CIMAGO, Faculty of Medicine, University of Coimbra, Coimbra, Portugal

4 CNC.IBILI, University of Coimbra, Coimbra, Portugal

5 Obstetrics Service, Coimbra Hospital and University Centre, Coimbra, Portugal

6 Blood and Transplantation Center of Coimbra, Portuguese Institute of the Blood and Transplantation, Coimbra, Portugal

7 Cytometry Operational Management Unit, Clinical Pathology Department, Coimbra Hospital and University Centre, Coimbra, Portugal
(MDR) proteins in HCC cell lines. In conclusion, hAMPE has several targets in HCC, being clear that the success of this treatment depends of a personalized therapy based on the biological and genetic characteristics of the tumor.

Keywords Human amniotic membrane $\cdot$ Hepatocellular carcinoma $\cdot$ Protein extracts $\cdot$ hAMPE $\cdot$ Oxidative stress $\cdot$ Cell cycle

\section{Introduction}

Human amniotic membrane (hAM) is one of the oldest biomaterials applied in regenerative medicine [1]. In 1910, Davis reported its application in skin transplantation [2]. Since then, hAM has been largely applied in several medical procedures in areas such as ophthalmology or burns treatment [3-6].

Until now, several authors reported successful in vitro and in vivo results that supported the theory that hAM could also be applied in cancer therapy. Magatti et al. [7] proved that hAMderived mesenchymal cells (hAMCs) significantly reduced proliferation of hematopoietic and non-hematopoietic cancer cell lines in cell-cell contact and transwell co-cultures. Cell cycle arrest at $\mathrm{G} 0 / \mathrm{G} 1$ phase was observed, as well as down-regulation of genes associated with cell cycle progression and upregulation of cell cycle negative regulators. Also, Jiao et al. [8] has found that hAMCs administration suppressed glioma tumor growth in vivo through the increase of pro-apoptotic proteins (BAX, caspase-3 and caspase- 8 ) and decrease of anti-apoptotic proteins (BCL2). hAMCs conditioned medium also have anti-carcinogenic properties, inhibiting prostate cancer cells proliferation and cell cycle [9]. Regarding the anticarcinogenic effect of hAM-derived epithelial cells (hAECs), Kang et al. [10] reported that hAECs were able to inhibit in 
vitro and in vivo breast cancer cells. In addition, a significant increase in apoptosis rate were observed in cancer cells treated with hAECs conditioned medium [11].

Recently, Mamede et al. [12] proved that hAM protein extracts (hAMPE) were able to inhibit some human cancer cell lines, such as hepatocellular carcinoma (HCC) cell lines (HuH7, HepG2 and Hep3B2.1-7). After hAMPE treatment, metabolic activity, protein content and deoxyribonucleic acid (DNA) content decreased in all HCC cell lines [13]. Through in vitro and in vivo studies, authors also proved that HCC cell death profile depends on the cell line signature [13]. Interestingly, hAMPE were not able to inhibit the metabolic activity, protein content and DNA content of a nontumorigenic human cell line (HFF-1) [13].

Given the lack of effective therapies for HCC, it is particularly important to find new therapies in order to reduce its mortality [14]. HCC develops in a complex and progressive process, due to several genetic and epigenetic modifications, in a rich oxidative stress environment $[15,16]$. These modifications induce autonomous cellular growth and consequent cell cycle deregulation, as well as several mutations in key proteins, such as P53, P21 and $\beta$-catenin [14, 16-18].

Usually, HCC is diagnosed in advanced stage and patients can no longer resort to curative therapies, such as transplantation or partial hepatectomy [19]. Palliative therapies include chemotherapy and radiotherapy. However, due to the chemoresistant and radioresistant $\mathrm{HCC}$ profile, these therapies often fail and are only applied in order to improve the patient's quality of life [18].

So, taking into account the results already published by our team $[12,13]$ and the urgency of new HCC therapies, this experimental study aimed to find the cellular targets of hAMPE in HCC through in vitro studies.

\section{Material and Methods}

Cell Culture Three human HCC cell lines were considered in this experimental study: HuH7, HepG2 and Hep3B2.1-7. HuH7 cells was purchased to Japanese Collection of Research Bioresources (JCRB, Japan). HepG2 and Hep3B2.1-7 cells were obtained from American Type Culture Collection (ATCC, USA). All cell lines were cultured in Dulbecco's Modified Eagle's Medium (DMEM - Sigma, D5648), pH 7.4, supplemented with $10 \%$ fetal bovine serum (FBS - Sigma, F7524), $1 \%$ antibiotic/antimycotic (Sigma, A5955) and $0.25 \%$ sodium pyruvate (Gibco, 11,360). Cells were maintained at $37{ }^{\circ} \mathrm{C}$ with $5 \% \mathrm{CO}_{2}$.

hAMPE Preparation hAM were obtained from healthy women after elective caesarean sections. The study was accomplished according to the recommendations of the Ethical Committee of the Coimbra Hospital and University Centre (CHUC-70-12, Coimbra, Portugal) after informed consent provided by women. After reception, hAM samples were washed with phosphate buffered solution [PBS: $137 \mathrm{mM}$ $\mathrm{NaCl}$ (Sigma, S7653), $2.7 \mathrm{mM} \mathrm{KCl}$ (Sigma, P9333), $10 \mathrm{mM}$ $\mathrm{Na}_{2} \mathrm{HPO}_{4}$ (Sigma, S3139), $2 \mathrm{mM} \mathrm{KH} \mathrm{PO}_{4}$ (Sigma, P0662), $\mathrm{pH}=7.4]$ supplemented with $2 \%$ antibiotic/antimycotic. hAMPE were prepared as previously described [12]. Briefly, PBS was added to the minced hAM samples and then hAMPE was prepared through a mechanical procedure (homogenization, sonication and centrifugation). Supernatants were stored at $-80^{\circ} \mathrm{C}$ until protein quantification in NanoDrop (ND-1000 Spectrophotometer, USA). All protocol was performed on ice without detergents addiction.

Evaluation of Hydrogen Peroxide and Superoxide Radical Expression To evaluate the hAMPE effect on hydrogen peroxide and superoxide radical expression on HCC cell lines, the probes DCFH-DA and DHE were respectively used. DCFH-DA is a liposoluble non-fluorescent compound that is deacetylate by intracellular esterases in the cellular cytosol and, in the presence of hydrogen peroxide, is oxidized to DCF, a highly fluorescent compound. Regarding DHE, this compound crosses cell membrane and is converted by the superoxide radical to ethidium, a red fluorescent compound that intercalates into DNA. The quantified fluorescence of DCF or DHE is respectively proportional to the concentration of intracellular hydrogen peroxide or superoxide radical [20, 21]. To perform this assay, $1 \times 10^{6}$ cells were incubated with $1 \mu \mathrm{g} / \mu \mathrm{L}$ of hAMPE for $72 \mathrm{~h}$. After, cells were incubated with $1 \mu \mathrm{L}$ of DCFH (5 mM - Sigma, D6883) or $5 \mu \mathrm{L}$ of DHE (1 mM - Sigma, 37,291) for $45 \mathrm{~min}$ or $15 \mathrm{~min}$, respectively, at $37^{\circ} \mathrm{C}$ in the dark. Cells were then centrifuged $(1300 \times \mathrm{g}$ for $5 \mathrm{~min}$ ), ressuspended in PBS and DCF fluorescence was determined at $485 / 20 \mathrm{~nm}$ excitation and 528/20 nm emission, as well as DHE fluorescence was determined at $530 / 25 \mathrm{~nm}$ excitation and 645/40 nm emission [22].

Evaluation of Reduced Glutathione (GSH) Expression In order to evaluate the GSH expression in HCC cell lines after hAMPE treatment, we resorted to orange mercury, a fluorescent compound that readily reacts with GSH producing an intense and fluorescent red product [23]. In order to perform this assay, $1 \times 10^{6}$ cells were incubated with $1 \mu \mathrm{g} / \mu \mathrm{L}$ of hAMPE. After $72 \mathrm{~h}$, cells were incubated with $4 \mu \mathrm{L}$ of orange mercury (10 mM - Sigma, M7750) for $15 \mathrm{~min}$ at $37^{\circ} \mathrm{C}$ in the dark. Cells were then centrifuged $(1300 \times \mathrm{g}$ for $5 \mathrm{~min})$, ressuspended in PBS and fluorescence was determined at 485/20 nm excitation and 590/35 nm emission [24].

Evaluation of DNA Damage To evaluate if hAMPE modifies DNA structural integrity of the HCC cell lines, two techniques were considered: polyethylene glycol (PEG)/Hoechst fragmentation assay and comet assay. To perform both assays, $1 \times 10^{6}$ cells were incubated with $1 \mu \mathrm{g} / \mu \mathrm{L}$ of hAMPE for 
72 h. To perform PEG/Hoechst fragmentation assay, lysis buffer $(0.1 \%$ Triton X-100 [Merk Millipore, 108,603], $5 \mathrm{mM}$ Trizma base [Sigma, T1503], pH 8.0, 20 mM EDTA [Sigma, E6758]) was added, followed by PEG (2.5 \% - Sigma, 1,546,605) and $\mathrm{NaCl}$ (1 M - Sigma, S7653). Cells were placed on ice for $10 \mathrm{~min}$ and centrifuged $(16000 \times \mathrm{g}$ for $10 \mathrm{~min})$. Hoechst 33,258 (0.2 $\mu \mathrm{g} / \mathrm{mL}$ in PBS, pH $7.4-$ Sigma, B1155) was added to supernatant (1:1) and, after $20 \mathrm{~min}$ of incubation at room temperature, the fluorescence was determined at 360/40 nm excitation and 460/40 nm emission [25]. Regarding the comet assay, cells $\left(5 \times 10^{4}\right.$ cells $\left./ \mathrm{mL}\right)$ were diluted in low melting point agarose (1\% - Sigma, A9414) (1:1) and applied in slides (Starfrost), previously overlaid with normal melting point agarose (1 \% - Sigma, A2790). The slides were submerged in alkaline lysis solution $(2.5 \mathrm{M}$ $\mathrm{NaCl}, 100 \mathrm{mM}$ EDTA, $10 \mathrm{mM}$ Trizma base, $10 \%$ DMSO [Sigma, D5879] and $1 \%$ Triton X-100) overnight. After, slides were equilibrated in alkaline electrophoresis buffer (300 mM NaOH [Sigma, S5881] and $1 \mathrm{mM}$ EDTA, $\mathrm{pH}>13$ ) and then were submitted to a potential difference of $254 \mathrm{~V}$ and current of $600 \mathrm{~mA}$ for $15 \mathrm{~min}$. After electrophoresis, slides were incubated in neutralizing buffer $(0.4 \mathrm{M}$ Trizma base, $\mathrm{pH}=7.5$ ) for 3 times, 5 min each. Staining with $20 \mu \mathrm{g} / \mathrm{mL}$ of ethidium bromide (BioRad, 161-0433) for $20 \mathrm{~min}$ were performed. After, slides were washed in distilled water and visualized in a fluorescent inverted microscope Motic with excitation at 540/25 nm and emission at 605/ $55 \mathrm{~nm}$. Image acquisition was performed in Motic Images 2.0 (Microscope world, EUA) [26].

Evaluation of Cell Cycle To assess cell cycle in HCC cell lines after hAMPE treatment, propidium iodide (PI) assay was used. PI has the ability to intercalate into DNA allowing, through their quantification, to study the different cell cycle stages. Once PI also has the ability to intercalate into ribonucleic acid (RNA), RNase must be used. Therefore, to evaluate if hAMPE treatment induced cell cycle alterations, $1 \times 10^{6}$ cells were incubated with $1 \mu \mathrm{g} / \mu \mathrm{L}$ of hAMPE. After $72 \mathrm{~h}$, cells were collected, centrifuged $(1300 \times \mathrm{g}$ for $5 \mathrm{~min})$ and fixed under stirring with $200 \mu \mathrm{L}$ of ice-cold ethanol (70\% - Sigma, 24, $102)$ for $30 \mathrm{~min}$ at $4{ }^{\circ} \mathrm{C}$. After centrifugation $(1300 \times \mathrm{g}$ for $5 \mathrm{~min}$ ), $200 \mu \mathrm{L}$ of PI/RNase (Immunostep) was added. Cells were then homogenized and incubated in the dark for $15 \mathrm{~min}$. After, cells were homogenized and analyzed into a FACSCalibur cytometer (Becton Dickinson, San José, USA) with an excitation and emission wavelength of $488 \mathrm{~nm}$ and $585 / 42 \mathrm{~nm}$, respectively. Results were analyzed in the ModFit LT software (Verity Software House) [26, 27].

Evaluation of P53 and $\beta$-Catenin Expression In order to evaluate the effect of hAMPE in P53 and $\beta$-catenin expression, $1 \times 10^{6}$ cells were incubated with $1 \mu \mathrm{g} / \mu \mathrm{L}$ of hAMPE for $72 \mathrm{~h}$. To prepare total protein extracts, cells were incubated on ice with radioimmunoprecipitation (RIPA) buffer supplemented with Complete Mini (Roche, 11,836,153,001), PhosSTOP (Roche,04,906,845,001) and $1 \mathrm{mM}$ dithiothreitol (DTT Sigma, 43,815), sonicated and centrifuged $(14000 \times \mathrm{g}$ for $15 \mathrm{~min}$ ). Protein samples were then reserved at $-80{ }^{\circ} \mathrm{C}$ until use. Bicinchoninic (BCA) assay (Pierce BCA protein assay kit) was used to determine protein concentration. After sample denaturation, electrophoresis was performed with an acrylamide gel. Proteins were then electrotransfered to methanol activated polyvinylidene fluoride (PVDF) membranes (Merck Millipore) $(100 \mathrm{~V})$. PVDF membranes blocking was performed with $4 \%$ bovine serum albumin (BSA - Sigma A7906) in tris-buffered saline tween-20 (TBS-T) under stirring for $1 \mathrm{~h}$ at room temperature. Incubation with primary antibodies, P53 (1:200 - Santa Cruz Biotechnology, sc-47, 698), $\beta$-catenin (1:200 - Santa Cruz Biotechnology, sc-7963) and $\beta$-actin (1:5000 - Sigma, A5441) was performed overnight at $4{ }^{\circ} \mathrm{C}$. After TBS-T several washes, membranes were incubated with anti-mouse secondary antibody (1:3000 - GE Healthcare) for $1 \mathrm{~h}$ at room temperature. After new washes, blots were stained with fluorescent reagent elemental chlorine free (ECF - Amersham Biosciences) for $5 \mathrm{~min}$ and revealed in a fluorescence reader (Typhoon FLA 9000). Quantification of fluorescence was performed using ImageQuant 5.0 (Molecular Dynamics) [26]. Hep3B2.1-7 cell line has a null P53, as already proved by our team, reason why we not provided P53 results for this cell line [28, 29].

Evaluation of P-Glycoprotein (PGP), Multidrug Resistance Protein 1 (MRP1), Lung Resistance Protein (LRP) and P21 Expression In order to evaluate if hAMPE induced PGP, MRP1, LRP and P21 expression alteration, $1 \times 10^{6}$ cells were incubated with $1 \mu \mathrm{g} / \mu \mathrm{L}$ of hAMPE for $72 \mathrm{~h}$. To evaluate PGP and MRP1 expression, cells were collected, centrifuged $(1300 \times \mathrm{g}$ for $5 \mathrm{~min})$ and incubated with $3 \mu \mathrm{L}$ of PGP-fluorescein isothiocyanate (FITC - BD Pharmingen, 557,002) or $3 \mu \mathrm{L}$ of MRP1-FITC (BD Pharmingen, 557,593) for $15 \mathrm{~min}$ in dark. After, cells were centrifuged $(1300 \times \mathrm{g}$ for $5 \mathrm{~min})$ and ressuspended in PBS. Fluorescence was determined at 485/20 nm emission and $528 / 20 \mathrm{~nm}$ emission. In order to evaluate LRP and P21 expression, cells were collected, centrifuged $(1300 \times \mathrm{g}$ for $5 \mathrm{~min})$ and incubated with $100 \mu \mathrm{L}$ of fix solution (IntraCell, Immunostep) for $15 \mathrm{~min}$. After centrifugation $(1300 \times \mathrm{g}$ for $5 \mathrm{~min}$ ), cells were then incubated for $15 \mathrm{~min}$ with $100 \mu \mathrm{L}$ of permeabilization solution (IntraCell, Immunostep) and LRP (1:50 - Santa Cruz Biotechnology, sc-23,916) or P21 (1:50 Santa Cruz Biotechnology, sc-6246). After centrifugation (1300 $\mathrm{g}$ for $5 \mathrm{~min}$ ), cells were then incubated with antimouse-PE secondary antibody (1:100 - Santa Cruz Biotechnology, sc-3738) for 20 min in dark. Cells were then centrifuged $(1300 \times \mathrm{g}$ for $5 \mathrm{~min})$, ressuspended in PBS and 
fluorescence was determined at 485/20 nm emission and 590/ $35 \mathrm{~nm}$ emission [30, 31].

\section{Statistical Analysis}

Statistical analysis was performed in IBM $^{\circledR}$ SPSS $^{\circledR}$ software v.22.0 (IBM Corporation, Armonk, New York, USA). The normality distribution of the variables and the homogeneity of variances were performed according to the Shapiro-Wilk and Levene tests, respectively. For comet assay, the normality distribution of the variables were determined through Kolmogorov-Smirnov test. Parametric Student t-test was used if a normal distribution and homogeneity of variances were observed. Otherwise, Mann-Whitney nonparametric test was considered. If a normal distribution and homogeneous variances were present, and in order to compare different cell lines, one-factor analysis of variance (ANOVA) parametric test was used. Otherwise Kruskal-Wallis nonparametric test was used. Multiple comparisons were obtained through Tukey (equal variances assumed) or Games-Howell (no equal variances assumed) corrections. A significant level of $5 \%$ was adopted for all comparisons.

\section{Results}

\section{hAMPE Modified the Oxidative Stress Environment in HCC Cell Lines}

hAMPE induced an increase of $39 \%(p<0.05)$ in hydrogen peroxide levels in $\mathrm{HuH} 7$ cell line relatively to control, as can be seen in Fig. 1a. On the other hand, hAMPE decreased the levels of this compound by $52 \%$ and $39 \%$ in HepG2 and Hep3B2.1-7 cells, respectively $(p<0.05)$. Regarding the superoxide radical (Fig. 1a), hAMPE decreased $42 \%(p<0.05)$ its expression in $\mathrm{HuH} 7$ cell line. Contrarily, the same treatment induced a superoxide radical increase of $288 \%$ $(p<0.01)$ and $37 \%(p<0.05)$ in HepG2 and Hep3B2.1-7 cell lines, respectively. hAMPE significantly decreased the expression of GSH in all HCC cell lines when compared to control cells (Fig. 1b).

\section{hAMPE Targeted DNA in HepG2 Cell Line}

Through Fig. 2a, it can be seen that hAMPE induced in increase of $32 \%(p<0.05)$ in DNA fragmentation in HepG2 cell line. This cell line also presented an increase of 13 times $(p<0.001)$ in the tail moment after hAMPE treatment, relatively to control condition (Fig. $2 \mathrm{~b}$ and $2 \mathrm{c}$ ). No changes were detected in DNA fragmentation or tail moment on $\mathrm{HuH7}$ and Hep3B2.1-7 cell lines.
hAMPE Modified Cell Cycle Profile in HCC Cell Lines

hAMPE treatment decreased the percentage of $\mathrm{HuH7}$ cells in G0/G1 phase $(p<0.05)$ and increased the number of cells in $\mathrm{G} 2 / \mathrm{M}$ phase $(p<0.05)$, as represented in Fig. 3a. Through Fig. 3b, it can be seen that the percentage of cells in $\mathrm{S}$ phase decreased $17 \%(p<0.05)$ and in $\mathrm{G} 2 /$ $\mathrm{M}$ phase increased $12 \%(p<0.05)$ relatively to control condition in the HepG2 cell line. On the other hand, hAMPE treatment decreased $48 \%$ of cells in $\mathrm{G} 0 / \mathrm{G} 1$ $(p<0.01)$ phase in Hep3B2.1-7 cell line, as well as increased $5 \%$ of cells in $\mathrm{S}$ phase $(p<0.01)$ (Fig. 3c).

\section{hAMPE Regulated P21, P53 and $\beta$-Catenin Expression in HCC Cell Lines}

The P21 expression increased $17 \%(p<0.05)$ after hAMPE treatment in $\mathrm{HuH} 7$ cell line, as disclosed in Fig. 4a. In contrast, these treatment induced a decreased of $11 \%(p<0.05)$ in P21 expression in HepG2 cell line and it was not able to change P21 expression in Hep3B2.1-7 cells. P53 expression was inhibited by hAMPE in HuH7 and HepG2 cell lines, as can be seen in Fig. $4 \mathrm{~b}(p<0.01)$. hAMPE was also able to inhibit $\beta$-catenin in all HCC cell lines $(p<0.01)$, when compared to control condition (Fig. 4c).

\section{hAMPE Regulated the Expression of Multidrug Resistance Proteins (MDR) in HCC Cell Lines}

After hAMPE treatment, PGP expression decreased $42 \%$ $(p<0.01)$ in Hep3B2.1-7 cell line (Fig. 5a). Regarding MRP1, its expression was $5 \%$ reduced by hAMPE in HepG2 cell line $(p<0.05)$, as can be seen in Fig. 5 b. Regarding the LRP multidrug resistance protein, its expression is not affected by hAMPE in any of the HCC cell lines under study (Fig. 5c).

\section{Discussion}

The interest in hAM anticancer potential has been growing in the last decade. However, despite the published results so far, the action mechanisms by which hAM exerts its effects on the tumor cells are not yet fully understood [7-10].

In order to discover some of the hAMPE molecular targets, and taking into account the previously published results [12, 13], we proposed to evaluate in vitro the effect of this therapy on several cellular molecules and its mechanisms on three human HCC cell lines.

Through the obtained results, it can be concluded that hAMPE modified the HCC oxidative stress environment. The increase of superoxide radical in HepG2 and 


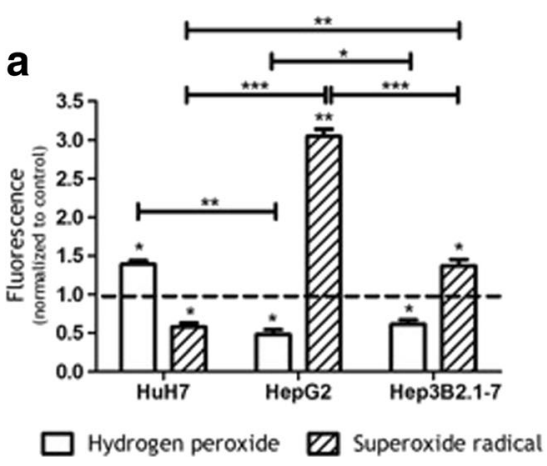

Fig. 1 a Hydrogen peroxide, superoxide radical and b GSH expression in $\mathrm{HuH} 7, \mathrm{HepG} 2$ and Hep3B2.1-7 cell lines after $72 \mathrm{~h}$ of incubation with $1 \mu \mathrm{g} / \mu \mathrm{L}$ of hAMPE. All results are normalized relatively to control condition (no hAMPE treatment), which was considered equal to 1 . For

Hep3B2.1-7 cells is probably a result of the high mitochondrial membrane potential (MMP) induced by hAMPE treatment, which is in accordance to previously demonstrated [13, 32]. On the other hand, a decrease in superoxide radical was observed in $\mathrm{HuH} 7$ cell line, which can be probably explained by a fast dismutation of this reactive oxygen species (ROS) by the superoxide dismutase (SOD) to hydrogen peroxide, whose levels in these cell line increased after hAMPE treatment [33]. The decrease of hydrogen peroxide in HepG2 and Hep3B2.1-7 cell lines can be probably promoted by a fast conversion of these ROS in other species more harmful to the cell, such as the hydroxyl radical, by the Fenton/Habber Weiss reaction [33, 34].

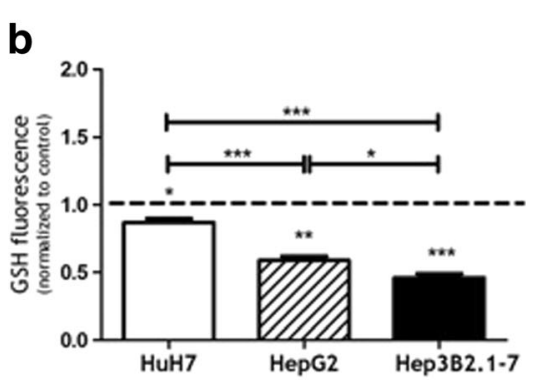

each condition, results were obtained with a minimum of three hAM. Graphs represent mean \pm standard error. Significant differences are indicated by $*$, where $*$ represents $p<0.05,{ }^{* *}$ represents $p<0.01$ and *** represents $p<0.001$

Hydrogen peroxide is efficiently scavenged by the enzyme glutathione peroxidase (GPx), which requires GSH as electron donor [33]. Since the levels of hydrogen peroxide decreased after hAMPE treatment in HepG2 and Hep3B2.1-7 cell lines, cellular GSH production also decreased since was no longer necessary for cell detoxification. Previous published results by our team suggested that intracellular NADPH was compromised after hAMPE treatment, since the metabolic activity (evaluated through the MTT reaction with NADPH) was inhibited [13]. Taking into account that oxidised glutathione (GSSG) is reduced back to GSH by the enzyme glutathione reductase, which uses NADPH as electron donor, the GSH
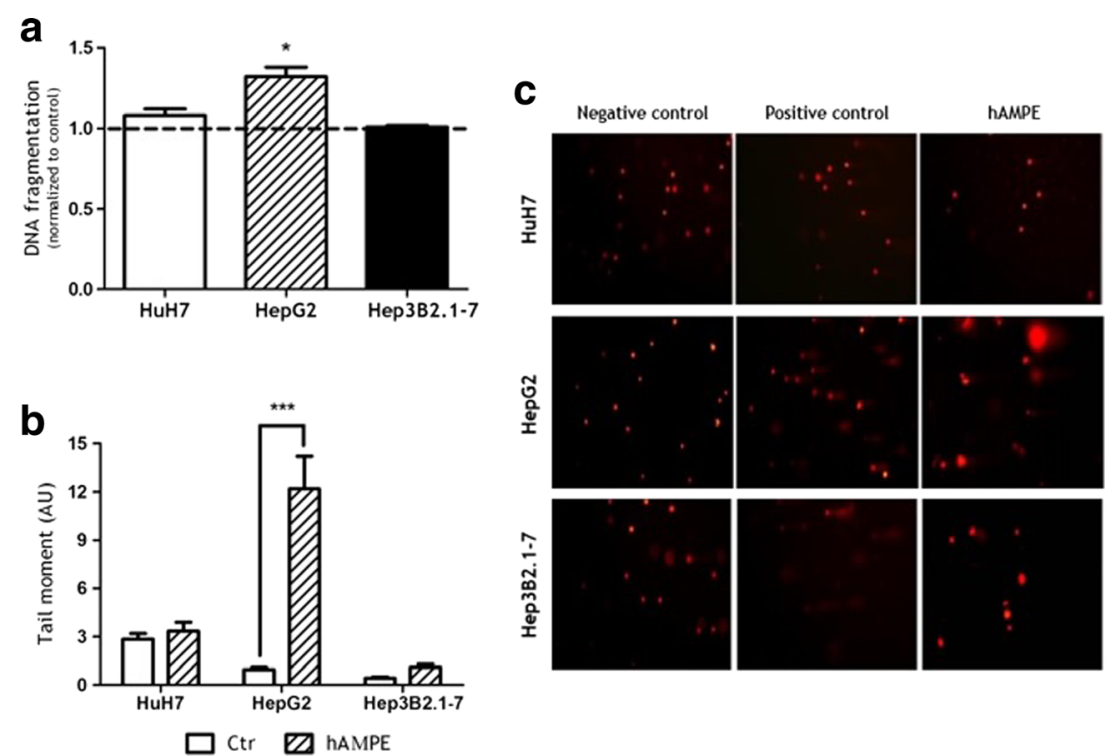

Fig. 2 DNA integrity accessed by (a) PEG-Hoechst fragmentation assay and (b/c) comet assay in HuH7, HepG2 and Hep3B2.1-7 cell lines after $72 \mathrm{~h}$ of incubation with $1 \mu \mathrm{g} / \mu \mathrm{L}$ of hAMPE. In (A) all results are normalized relatively to control condition (no hAMPE treatment), which was considered equal to 1 . (b) Tail moment $=$ tail length $\mathrm{x}$ fraction of total DNA in the tail. The data are based on a minimum of 100 comets per condition. For each condition presented in (a) and (b),

results were obtained with a minimum of three hAM. Graphs represent mean \pm standard error. Significant differences are indicated by *, where * represents $p<0.05$ and $* * *$ represents $p<0.001$. (c) Representative images of the comet assay for each condition: negative control (untreated cells $-100 \times$ ), positive control [cells treated with $20 \mathrm{nM}$ of hydroxide peroxide (Panreac, 121,076) for $15 \mathrm{~min}$ at $\left.4{ }^{\circ} \mathrm{C}-100 \times\right]$ and hAMPE treated cells $(100 \times)$ 

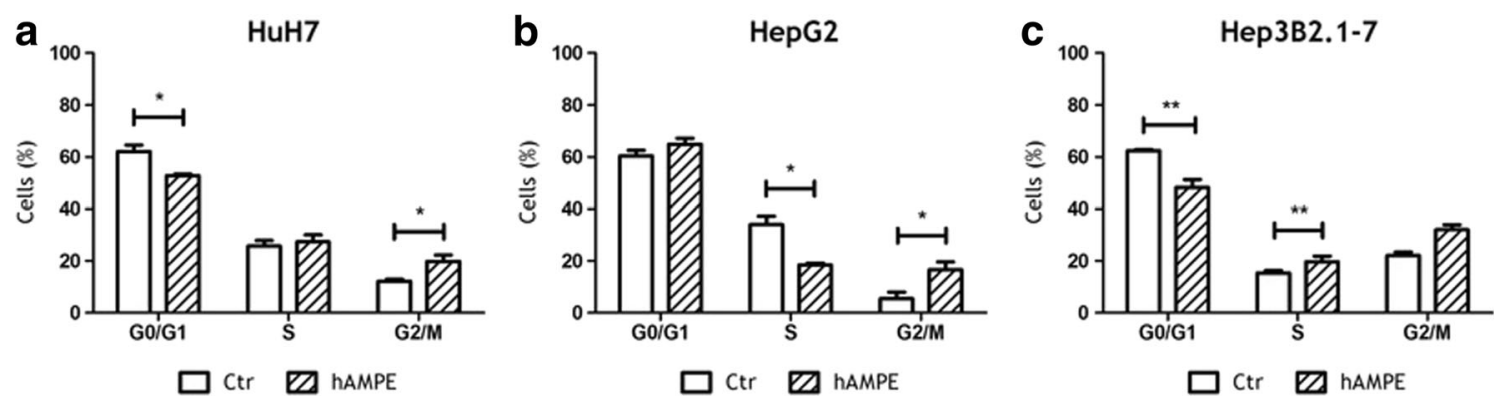

Fig. 3 Cell cycle analysis of $\mathrm{HuH7}$ (a), HepG2 (b) and Hep3B2.1-7 (c) cell lines after $72 \mathrm{~h}$ of incubation with $1 \mu \mathrm{g} / \mu \mathrm{L}$ of hAMPE. Results represent the percentage of cells in the different cell cycle phases: G0/ G1, S and G2/M. For each condition, results were obtained with a

decrease in all HCC cell lines can be also a consequence of cellular NADPH commitment [33].

PEG-Hoechst assay allows to quantify small-size $(0-1 \mathrm{~kb})$ fragmented DNA [35]. These fragments are indicators of necrotic and apoptotic DNA damage [35]. So, in accordance with the results obtained, hAMPE induced an increase of DNA fragmentation in HepG2 cells, which can corroborate the apoptotic and necrotic cell death profile induced by hAMPE in these cell lines [13]. In order to support these results, comet assay, which allows to detect single and double strand breaks, was used to evaluate the effect of hAMPE [26]. These results also corroborated the effect triggered by hAMPE in DNA damage, being this significantly increased in HepG2 cells. The highest levels of superoxide radical in HepG2 cell line after hAMPE treatment could probably trigger DNA damage and consequent apoptosis and necrosis [36]. Supporting this effect is the fact that no DNA damage were observed in HuH7 and Hep3B2.1-7 cell lines, which presents low levels of superoxide radical when compared to HepG2 cells. However, we cannot exclude the possibility of intrastranded or interstranded crosslinking formation [26]. Since we previously minimum of three hAM. Graphs represent mean \pm standard error. Significant differences are indicated by $*$, where * represents $p<0.05$ and $* *$ represents $p<0.01$

found that hAMPE induced apoptosis in these cell lines, we can conclude that $\mathrm{HuH} 7$ and Hep3B2.1-7 cells may undergo apoptosis without DNA fragmentation [13]. Although is not a common profile, there are several studies published about early apoptosis without DNA fragmentation induction $[37,38]$.

P21 expression is commonly up-regulated by the P53 tumor suppressor gene [39]. However, P21 expression can also be P53-independently regulated [39]. Since hAMPE decreased P53 expression in $\mathrm{HuH} 7$ cell line, $\mathrm{P} 21$ increase in this cell line was probably induced by an independent P53 mechanism. On the other hand, in wild-type P53 HepG2 cell line, P21 decreased was probably a direct consequence of P53 inhibition by hAMPE treatment. P53 inhibition could be a consequence of the high DNA damage induced by hAMPE in HepG2 cell line, since P53 is one of the main responsible for DNA repair mechanisms [40].

It is well known that P21 might inhibit cell cycle progression by two independent mechanisms: inhibition of cyclin/cyclin-dependent kinase (CDK) complexes and inhibition of proliferating cell nuclear antigen (PCNA) function, which results in both G1 and G2 arrest [41]. Since
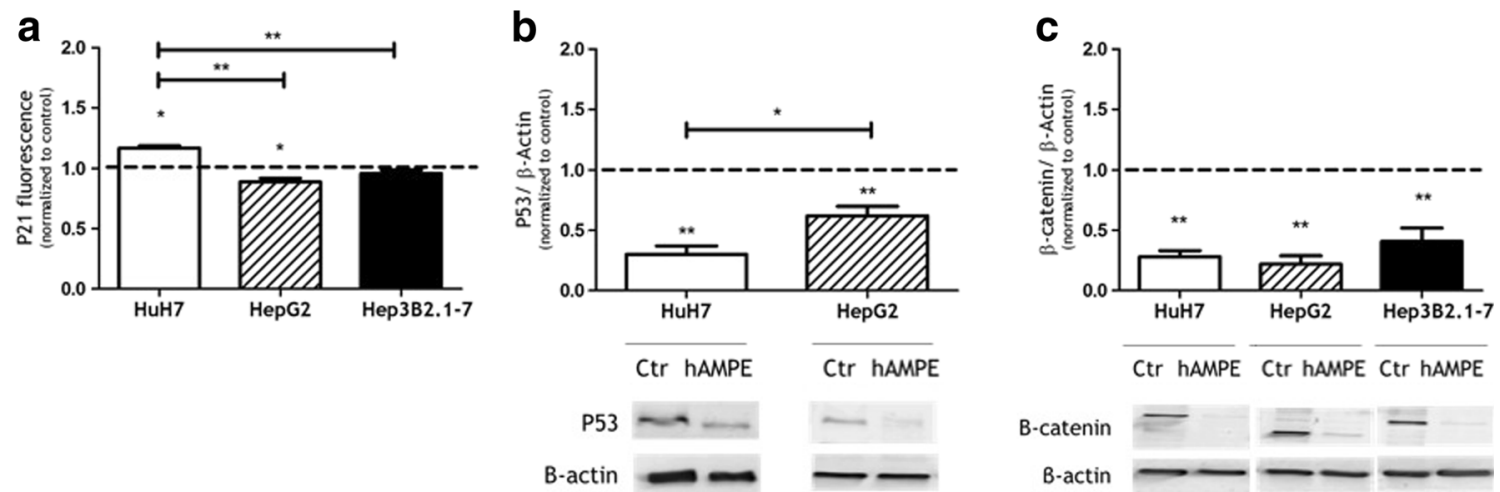

Fig. 4 Expression of P21 (a), P53 (b) and $\beta$-catenin (c) in HuH7, HepG2 and Hep3B2.1-7 cells after incubation with $1 \mu \mathrm{g} / \mu \mathrm{L}$ f hAMPE for $72 \mathrm{~h}$. All results are normalized relatively to control condition (no hAMPE treatment) which was considered equal to 1 . Results presented in $\mathrm{B}$ and $\mathrm{C}$ are presented as the fluorescence intensities ratio between the protein of

interest and $\beta$-actin and are representative of $\mathrm{P} 53$ or $\beta$-catenin and $\beta$-actin expression for each experimental condition. For each condition, results were obtained with a minimum of three hAM. Graphs represent mean \pm standard error. Significant differences are indicated by $*$, where * represents $p<0.05$ and ${ }^{* *}$ represents $p<0.01$ 

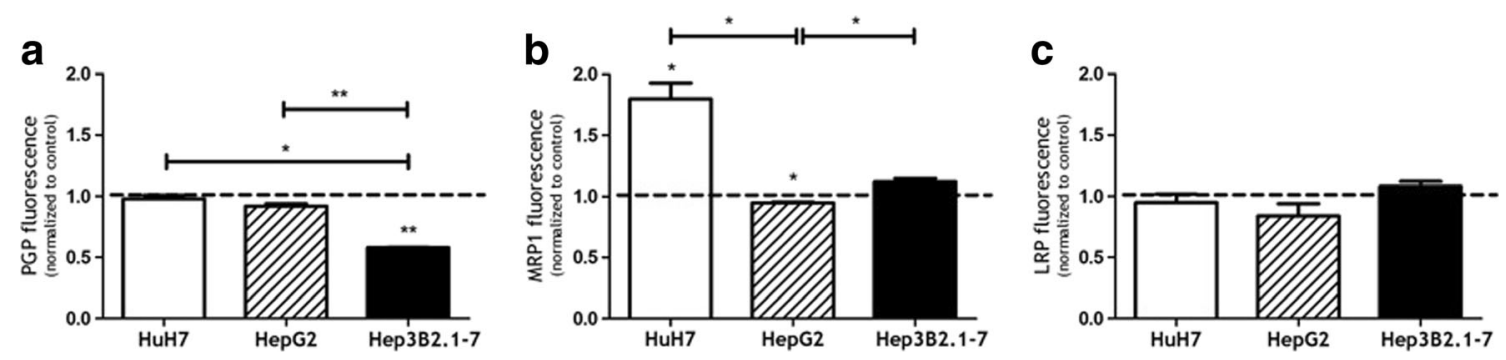

Fig. 5 Expression of PGP (a), MRP1 (b) and LRP (c) in HuH7, HepG2 and Hep3B2.1-7 cells after incubation with $1 \mu \mathrm{g} / \mu \mathrm{L}$ of hAMPE for $72 \mathrm{~h}$. All results are normalized relatively to control condition (no hAMPE treatment) which was considered equal to 1 . For each condition, results were obtained with a minimum of three hAM. Graphs represent mean \pm standard error. Significant differences are indicated by *, where * represents $p<0.05$ and ${ }^{* *}$ represents $p<0.01$
hAMPE induced G2/M phase arrest in $\mathrm{HuH7}$ cell lines, it was likely that increased P21 inhibited PCNA. Since PCNA acts as a scaffold protein that organizes several components for DNA replication or cell cycle progression, PCNA inhibition could probably be responsible for several experimental results presented by our team in this and other papers $[13,42]$. On the other hand, since hAMPE induced a high DNA damage in HepG2 cell line, and since G2/M checkpoint is essential for maintaining genome stability, the HepG2 cell cycle arrest in this phase could be easily explained [43]. Wu et al. [44] revealed that Wnt pathway inhibition induced a cell cycle arrest at G2/M and S phase in HuH7 and Hep3B2.1-7 cell lines, respectively. Considering the similarity with our results, we should conduct further studies in the future to analyse if hAMPE is able to inhibit the Wnt pathway in HCC cell lines. Taking into account our results previously published [13], the reduction of P53 and $\beta$-catenin in all HCC cell lines can explain the decreased metabolic activity, protein content, DNA content and cell death induced by hAMPE treatment [44].

Low response rates to chemotherapy in $\mathrm{HCC}$ can partly be attributed to the expression of MDR proteins [30]. In order to overcome this problem, pharmacologic inhibition of MDR transporters has been largely studied, since pharmacological inhibitors application is based on 1) modulation of MDR protein activity by competitive inhibition or 2) induction of conformational changes in MDR proteins, thus preventing substrate recognition or ATP hydrolysis [31]. In accordance with our results, we can conclude that hAMPE is able to inhibit PGP expression in Hep3B2.1-7 cells and MRP1 expression in HepG2 cells.

On the other hand, hAMPE induced an increase of MRP1 protein expression in HuH7 cell line. This results could explain the higher efficacy of hAMPE therapy in HepG2 and Hep3B2.1-7 cell lines than in HuH7 cell line, as clearly demonstrated through in vitro and in vivo studies previously published [13]. It is actually known that the expression of certain P53 mutants in HCC may enhance drug resistance $[45,46]$. Since HuH7 cell line expresses a mutated P53, this protein could be responsible for the drug resistance. Through our results it seems that LRP is not a target of hAMPE in any of the HCC cell lines under study.

In conclusion, it seems that hAMPE is able to modify the oxidative stress environment in all HCC cell lines, as well as their cell cycle. This treatment also differently targets DNA, P21, P53, $\beta$-catenin and MDR proteins in HCC cell lines. However, through this experimental study, it becomes clear that hAMPE treatment output depends on the biological and genetic characteristic of each cell line.

Acknowledgments Ana Catarina Mamede (SFRH/BD/73649/2010) and Maria João Carvalho (SFRH/SINTD/60068/2009), wishes to thank to Portuguese Foundation for Science and Technology for their PhD Grants. The authors would also like to thank Obstetrics Service of Coimbra Hospital and University Centre for the collection of human tissues used in this work. Support: Santander Totta; Infarmed (Health Research Fund 2015); FCT, Portugal (Strategic Project PEst-C/SAU/ UI3282/2013 and UID/NEU/04539/2013), COMPETE-FEDER.

Compliance with Ethical Standards All procedures performed in studies involving human participants were in accordance with the ethical standards of the institutional and/or national research committee and with the 1964 Helsinki declaration and its later amendments or comparable ethical standards.

Conflicts of Interest The authors declare that they have no conflicts of interest.

Informed Consent Informed consent was obtained from all individual participants included in the study.

\section{References}

1. Toda A, Okabe M, Yoshida T, Nikaido T (2007) The potential of amniotic membrane/amnion-derived cells for regeneration of various tissues. J Pharmacol Sci 105:215-228

2. Davis J (1910) Skin transplantation with a review of 550 cases at the Johns Hopkins Hospital. Johns Hopkins Med J 15:307 
3. Gomes J, Romano A, Santos M, Dua H (2005) Amniotic membrane use in ophthalmology. Curr Opin Ophthalmol 16:233-240

4. Dua H, Azuara-Blanco A (1999) Amniotic membrane transplantation. Br J Ophthalmol 83:748-752

5. Sawhney C (1989) Amniotic membrane as a biological dressing in the management of burns. Burns 15:339-342

6. Mamede A, Carvalho M, Abrantes A, et al. (2012) Amniotic membrane: from structure and functions to clinical applications. Cell Tissue Res 349:447-458

7. Magatti M, De Munari S, Vertua E, Parolini O (2012) Amniotic membrane-derived cells inhibit proliferation of cancer cell lines by inducing cell cycle arrest. J Cell Mol Med 16:2208-2218

8. Jiao H, Guan F, Yang B, et al. (2012) Human amniotic membrane derived-mesenchymal stem cells induce C6 glioma apoptosis in vivo through the bcl-2/caspase pathways. Mol Biol Rep 39:467473

9. Rolfo A, Giuffrida D, Giuffrida M, et al. (2014) New perspectives for prostate cancer treatment: in vitro inhibition of LNCaP and PC3 cell proliferation by amnion-derived mesenchymal stromal cells conditioned media. Aging Male 17: 94-101

10. Kang N-H, Yi B-R, Lim S, et al. (2012) Human amniotic membrane-derived epithelial stem cells display anticancer activity in $\mathrm{BALB} / \mathrm{c}$ female nude mice bearing disseminated breast cancer xenografts. Int J Oncol 40:2022-2028

11. Niknejad H, Khayat-Khoei M, Peirovi H, Abolghasemi H (2014) Human amniotic epithelial cells induce apoptosis of cancer cells: a new anti-tumor therapeutic strategy. Cytotherapy 16 : 33-40

12. Mamede A, Laranjo M, Carvalho M, et al. (2014) Effect of amniotic membrane proteins in human cancer cell lines: an exploratory study. J Membr Biol 247:357-360

13. Mamede A, Guerra S, Laranjo M, et al. (2015) Selective cytotoxicity and cell death induced by human amniotic membrane in hepatocellular carcinoma. Med Oncol 32:257

14. Gomes M, Priolli D, Tralhão J, Botelho M (2013) Hepatocellular carcinoma: epidemiology, biology, diagnosis and therapies. Rev Assoc Med Bras 59:514-524

15. Ferlay J, Steliarova-Foucher E, Lortet-Tieulent J, et al. (2013) Cancer incidence and mortality patterns in Europe: estimates for 40 countries in 2012. Eur J Cancer 49:13741403

16. Marra M, Sordelli I, Lombardi A, et al. (2011) Molecular targets and oxidative stress biomarkers in hepatocellular carcinoma: an overview. J Transl Med 9:171

17. Alves R, Alves D, Guz B, et al. (2011) Advanced hepatocellular carcinoma: review of targeted molecular drugs. Ann Hepatol 10: 21-27

18. Brito A, Abrantes A, Pinto-Costa C, et al. (2013) Hepatocellular carcinoma and chemotherapy: the role of p53. Chemotherapy 58 : 381-386

19. Tralhão J, Abrantes A, Hoti E, et al. (2013) Hepatectomy and liver regeneration: from experimental research to clinical application. ANZ J Surg 84:665-671

20. Abrantes A, Serra M, Gonçalves A, et al. (2010) Hypoxia-induced redox alterations and their correlation with $99 \mathrm{mTc}-\mathrm{MIBI}$ and 99mTc-HL-91 uptake in colon cancer cells. Nucl Med Biol 37: $125-132$

21. Tralhão J, Abrantes A, Gonçalves A, et al. (2013) Study of hepatocellular function in the murine model following hepatic artery selective clamping. Acta Cir Bras 28:657-663

22. Gomes A, Fernandes E, Lima J (2005) Fluorescence probes used for detection of reactive oxygen species. J Biochem Biophys Methods 65:45-80
23. Mamede A, Pires A, Abrantes A, et al. (2012) Cytotoxicity of ascorbic acid in a human colorectal adenocarcinoma cell line (WiDr): in vitro and in vivo studies. Nutr Cancer 64:1049-1057

24. Larrauri A, López P, Gómez-Lechón M, Castell J (1987) A cytochemical stain for glutathione in rat hepatocytes cultured on plastic. J Histochem Cytochem 35:271-274

25. Ioannou Y, Chen F (1996) Quantitation of DNA fragmentation in apoptosis. Nucleic Acids Res 24:992-993

26. Santos K, Laranjo M, Abrantes A, et al. (2014) Targeting triple-negative breast cancer cells with 6,7-bis(hydroxymethyl)-1H, 3H-pyrrolo[1,2-c]thiazoles. Eur J Med Chem 79:273-281

27. Serra A, Am RG, Laranjo M, et al. (2012) Synthesis of new 2galactosylthiazolidine-4-carboxylic acid amides. antitumor evaluation against melanoma and breast cancer cells. Eur J Med Chem 53: 398-402

28. Brito A, Abrantes A, Ribeiro M, et al. (2015) Fluorine-18 fluorodeoxyglucose uptake in hepatocellular carcinoma: correlation with glucose transporters and p53 expression. J Clin Exp Hepatol 5:183-189

29. Gomes A, Abrantes A, Brito A, et al. (2015) P53 influence on the radiotherapy response of hepatocellular carcinoma. Clin Mol Hepatol 21:257-267

30. Brito A, Mendes M, Abrantes A, et al. (2014) Positron emission tomography diagnostic imaging in multidrug-resistant hepatocellular carcinoma: focus on 2-deoxy-2-(18F)fluoro-d-glucose. Mol Diagn Ther 18:495-504

31. Casalta-Lopes J, Abrantes A, Laranjo M, et al. (2011) Efflux pumps modulation in colorectal adenocarcinoma cell lines: the role of nuclear medicine. J Cancer Ther 02:408-417

32. Choi K, Kim J, Kim G, Choi C (2009) Oxidative stress-induced necrotic cell death via mitochondira-dependent burst of reactive oxygen species. Curr Neurovasc Res 6:213-222

33. Valko M, Leibfritz D, Moncol J, et al. (2007) Free radicals and antioxidants in normal physiological functions and human disease. Int J Biochem Cell Biol 39:44-84

34. Li Y, Schellhorn H (2007) New developments and novel therapeutic perspectives for vitamin C. J Nutr 137:2171-2184

35. Georgiou C, Papapostolou I, Grintzalis K (2009) Protocol for the quantitative assessment of DNA concentration and damage (fragmentation and nicks). Nat Protoc 4:125-131

36. Reuter S, Gupta S, Chaturvedi M, Aggarwal B (2010) Oxidative stress, inflammation, and cancer: how are they linked? Free Radic Biol Med 49:1603-1616

37. Oberhammer F, Wilson J, Dive C, et al. (1993) Apoptotic death in epithelial cells: cleavage of DNA to $300 \mathrm{and} / \mathrm{or} 50 \mathrm{~kb}$ fragments prior to or in the absence of internucleosomal fragmentation. EMBO J 12:3679-3684

38. Zamai L, Falcieri E, Marhefka G, Vitale M (1996) Supravital exposure to propidium iodide identifies apoptotic cells in the absence of nucleosomal DNA fragmentation. Cytometry 23:303-311

39. Macleod K, Sherry N, Hannon G, et al. (1995) p53-dependent and independent expression of $\mathrm{p} 21$ during cell growth, differentiation, and DNA damage. Genes Dev 9:935-944

40. Hussain S, Schwank J, Staib F, et al. (2007) TP53 mutations and hepatocellular carcinoma: insights into the etiology and pathogenesis of liver cancer. Oncogene 26:2166-2176

41. Cayrol C, Knibiehler M, Ducommun B (1998) p21 binding to PCNA causes G1 and G2 cell cycle arrest in p53-deficient cells. Oncogene 16:311-320

42. Punchihewa C, Inoue A, Hishiki A, et al. (2012) Identification of small molecule proliferating cell nuclear antigen (PCNA) inhibitor that disrupts interactions with PIP-box proteins and inhibits DNA replication. J Biol Chem 287: $14289-14300$ 
43. Stark G, Taylor W (2004) Analyzing the G2/M checkpoint. In: Schonthal AH (ed) Checkp. Control. cancer Rev. Model Syst. Humana Press, Totowa, pp. 51-82

44. Wu G, Xu L, Lin N, Liu B (2013) UCN-01 induces S and G2/M cell cycle arrest through the $\mathrm{p} 53 / \mathrm{p} 21$ wafl or $\mathrm{CHK} 2 / \mathrm{CDC} 25 \mathrm{C}$ pathways and can suppress invasion in human hepatoma cell lines. BMC Cancer 13:167
45. Chan K-T, Lung M (2004) Mutant p53 expression enhances drug resistance in a hepatocellular carcinoma cell line. Cancer Chemother Pharmacol 53:519-526

46. Tsang W-P, Chau S, Fung K-P, et al. (2003) Modulation of multidrug resistance-associated protein 1 (MRP1) by p53 mutant in saos2 cells. Cancer Chemother Pharmacol 51:161-166 